\title{
WHAT CONSTITUTES A MULTIDISCIPLINARY CAPSTONE DESIGN Course? Best Practices, SuCCesses ANd Challenges.
}

\author{
Kamran Behdinan ${ }^{1}$, Remon Pop-Iliev ${ }^{2}$ and Jason Foster ${ }^{1}$ \\ ${ }^{1}$ University of Toronto \\ ${ }^{2}$ University of Ontario Institute of Technology \\ Corresponding Author E-mail Address: behdinan@mie.utoronto.ca
}

\begin{abstract}
This paper reflects on how to practically achieve the necessary organizational and curricular preconditions that allow for conducting Multi Inter and Trans - disciplinary engineering capstone design industry sponsored projects and thereby serve engineering graduates better. The differences between offering multidisciplinary and the common singledisciplinary capstone design courses are also highlighted. Simultaneously, this paper focuses on the key challenges that aggravate the smooth implementation of such a complex undertaking the fundamental goal of which is to offer a multidisciplinary team-based design project work experience to the Students that would be mimicking as close as possible an analogue typical industrial setting. Possible remedial measures for overcoming these challenges are also discussed. A new multidisciplinary capstone design project course offered at the Faculty of Applied Science and Engineering (FASE) at the University of Toronto in the 2013/14 academic year ("APS 490Y Multidisciplinary Capstone Design") coordinated by Prof. Kamran Behdinan served as the basis for this work.
\end{abstract}

Keywords: design education, capstone, multidisciplinary design, interdisciplinary design, trans-disciplinary design.

\section{INTRODUCTION}

In addition to providing fundamental disciplinary technical expertise, contemporary engineering education has, and continue to evolve towards fostering multidimensional collaborative initiatives that develop forward looking, competent engineering professionals capable of balancing user focused design with the application of novel and transformative technologies to create radical innovations in products, processes, technologies, systems, or services. Consequently, multidisciplinary capstone design courses are often regarded as the crowning achievement of outcome-based curricula offered by accredited engineering programs in Canada.
By definition, multidisciplinary capstone design engineering courses are normally offered in the graduating year of an engineering program and represent culminating client-based design-build challenges that integrate solving real-life engineering problems in professional settings. These courses are intended to provide students with a unique opportunity to cumulatively integrate acquired theoretical knowledge with hands-on practice within their knowledge domain and that of teammates from other engineering fields.

The Canadian Engineering Accreditation Board (CEAB) currently recommends a multidisciplinary design approach through one of its twelve mandatory graduate attributes, as described in section 3.1.6: "Individual and team work: An ability to work effectively as a member and leader in teams, preferably in a multidisciplinary setting [1]." In contrast, in its newest publication that incorporates all changes approved by the ABET Board of Directors as of October 26, 2013, in Criterion 3: Student Outcomes, ABET strictly requires establishing as a Student outcome "(d) an ability to function on multidisciplinary teams [2]."

In this context, the primary objective of this paper is to propose a best practice for setting the preconditions, developing the structure, and successfully running capstone design courses that foster multidisciplinary, project-based, supervised academic interaction between graduating Students of various engineering programs and a broad spectrum of industry sectors and Clients.

\section{BACKGROUND}

The University of Toronto Institute for Multidisciplinary Design and Innovation (UT-IMDI) was approved and established in the Faculty of Applied Science and Engineering (FASE) in 2012 and is housed in the Department of Mechanical \& Industrial Engineering (MIE). Professor Kamran Behdinan (MIE) is the institute's inaugural director. The Institute, which was established as a result of the NSERC Chair in Multidisciplinary Engineering Design program, provides 
remarkable opportunities for Students to work on real-life projects with real Clients.

Projects are determined collaboratively, based on the needs of industry and building on the strengths of the Faculty. During the institute's inaugural year, nine undergraduate students from the departments of Mechanical \& Industrial Engineering, Materials Science $\&$ Engineering and Division of Engineering Science, landed exclusive aerospace jobs with Bombardier Aerospace, Pratt \& Whitney Canada, and UTC Aerospace Systems, completing their assignment over the summer and working under the supervision of a senior engineer and a faculty member [3].

First-time UT-IMDI Student Kristina Menton (MechE 1T4), appreciated the level at which her company, Pratt \& Whitney, designed for her a true employee experience. Her project, the validation of emissions for six of Pratt \& Whitney's engine models, gave her the opportunity to assist her supervisor with testing at the Montréal facility.

"What I appreciated about being a UT-IMDI Student is that they really put extra into my experience," says Menton, who is also completing a minor in sustainable energy. "When I went to Montréal, I got a tour of the plant and met a lot of people. It was above and beyond." "Before going to Pratt \& Whitney, I really knew nothing about professional engineering and industry research and development. I didn't know the processes and just how many different departments and areas there are within a company doing $R \& D$. It opened my eyes [3]."

The UT-IMDI has experienced significant growth since its inception in 2012 and in summer 2013 was able to provide 27 real-life projects in partnership with major automotive and aerospace companies.

To build on these early successes, Professor Behdinan and UT-IMDI were given the mandate to design and implement a new, multidisciplinary capstone design course. This mandate was endorsed by the FASE Dean and all engineering department chairs, and builds extensively on the innovative Engineering Strategies \& Practice (ESP) and Praxis course offerings in the first year.

The central focus of the new course was to provide multidisciplinary Student teams with the challenge of and opportunity to contribute directly to a real-life multidisciplinary capstone project (MCP) while closely communicating with industrial Clients. This is a "full year" course offered exclusively to fourth-year Students. Students have a choice between their departmental capstone design course and the MCP course. Interested Students from 9 participating departments may enroll in the course. The first offering of this course included 17 MCP projects, 12 Clients, and 68 Students. The number of MCPs will expectantly increase each year to reach more than 20 projects by year 5 .

\section{THE STRUCTURE OF THE MCP COURSE}

The Academic Calendar of the FASE for 2013/14 describes the course "APS 490Y Multidisciplinary Capstone Design" as an experience in multidisciplinary engineering practice through a significant design project whereby Student teams meet specific Client needs through a creative, iterative, and open-ended design process. As described in section 3.4, the course coordinator works with other members of the committee (largely composed of capstone design coordinators from other engineering programs within FASE) to implement the course. Recruiting and coordinating Students is the responsibility of the various FASE departments. All MCP projects are proposed by industry; Students work within a team of 3 to 5 and are supervised by faculty members from one or more departments (depending on the required knowledge and involved disciplines). The faculty supervisors meet with the Students regularly and are responsible for the assessment of the Students' design projects. The Students also meet and communicate with their industry client on a regular basis.

\subsection{CEAB Graduate Attributes of the MCP}

The CEAB Graduate Attributes (GAs) assessed in the MCP are compatible with those assessed in the related Capstone Design courses. The following GAs will be assessed for all MCP projects:

- A knowledge base for engineering (GA 3.1.1)

- Design (GA 3.1.4)

- Use of engineering tools (GA 3.1.5)

- Individual and team work (GA 3.1.6)

- Communication skills (GA 3.1.7)

- Professionalism (GA 3.1.8)

- Life-long learning (GA 3.1.12)

Depending on the specifics of the project, one or more the following additional GAs may be assessed with the approval of the Course Coordinator and Supervisor:

- Impact of engineering on society and the environment (GA 3.1.9)

- Ethics and equity (GA 3.1.10)

- Economics and project management (GA 3.11).

\subsection{What makes the MCP unique?}

The MCP is a capstone design course within the FASE that provides the enrolled Students with a unique opportunity to work with Students from other disciplines. All of the projects in the MCP have an industry Client for whom the project represents a real business need. All of the selected projects possess significant complexity, multidisciplinary nature, and high value of the outcome to 
the Client. As the projects are explicitly multidisciplinary in nature, successfully completing the project requires skills and knowledge from across multiple engineering disciplines. Students are also provided access to Subject Matter Experts (SMEs) from across the Faculty and from partner Faculties. Significant resources are committed and provided by the NSERC Design Chair and the FASE.

\subsection{MCP Student Expectations}

The MCP is intended for exceptional Students who are looking for a challenging capstone design experience. Students who are accepted into the MCP are excluded from taking their program's regular capstone design course. Students in the MCP must demonstrate:

- Use of knowledge, skills and processes from several disciplines to conduct engineering analysis and design.

- Engineering judgment in integrating economic, health, safety, environmental, social or other pertinent interdisciplinary factors.

- Elements of teamwork, project management and Client interaction.

- A demonstration of proof of the design concept.

\subsection{Governance of the MCP}

- Multidisciplinary Capstone Lead Committee. The FASE MCP Lead Committee was established in 2012 with membership from all engineering departments. It consists of 14 professors, many of whom teach or coordinate their departmental capstone design courses. The main purpose of the MCP Lead Committee is to address planning issues and to foster multidisciplinary capstone projects across the Faculty.

- Course Coordinator. Students who would like to work on an MCP project must apply to the Course Coordinator, with admission to the course based on demonstrated skills, knowledge, and experience as an engineering designer within their discipline. The Course Coordinator ensures a successful and equitable course experience.

- Course Assistant. Primary point of contact for course administrative issues.

- Departmental Representative. Liaise between the MCP and the respective department.

- Client. Initiate/support one or more design projects.

- Supervisor. Each MCP project has an associated Supervisor who will work with one or more Student Teams. The Supervisor is the primary point of contact for both the Client and the Teams, and is responsible for ensuring that both the Client's and the MCP's desired outcomes materialize. Supervisors are selected from among the pool of FASE design instructors.

- Subject Matter Experts (SMEs). Each MCP project also has associated Subject Matter Experts who provide discipline-focused support and assess to the incorporation of discipline-specific knowledge, tools, and skills into the design project to the Student Teams.

- Representatives from the Engineering Communication Program (ECP) are integrated into the MCP as SMEs.

- Students are required to comply with any agreements made between the MCP and the Client regarding intellectual property and nondisclosure.

\subsection{Required Deliverables of the MCP}

Project Requirements. The Project Requirements deliverable frames the Statement of Need as an engineering design project. Teams are expected to identify and consult with stakeholders (including the Client, SMEs, and Supervisor) and to undertake additional research (into, e.g., relevant Codes, Standards, norms of practice, etc.) to develop a complete and comprehensive framing. The Project Requirements also define the scope of the project.

Design Proposal. The Design Proposal deliverable codifies and documents a proposed solution that addresses the Project Requirements. The Proposal should document an iterative process of conceptual divergence, analysis, and convergence, including alternative designs that resulted in the proposed solution. The Design Proposal may also include reframed or additional requirements identified as the proposed solution was developed.

Design Review and Critique. The Design Review and Critique should be scheduled to enable as many stakeholders as possible to attend. Students should arrange for a recording if a key stakeholder cannot attend.

Design Showcase. The Design Showcase is a formal sharing of progress and information between the Team and their Supervisor and SMEs, with the Client in attendance.

Final Report and Deliverables. The Final Report and Deliverables close the relationship between the Client and the Team. The Final Report contains the complete design process from definition of the problem to the implementation of the solution and the results of testing (reflecting suitable iterations). It contains a discussion of the required future work in ufficient detail that the Client can implement the design without additional input from the Team.

Design Portfolio. The Design Portfolio deliverable captures evidence of Student design abilities and experiences. It supports Student claims of proficiency as an engineering designer, and is intended for a wide audience including their Supervisor and prospective employee. 


\subsection{Assessment of Deliverables of the MCP}

The deliverables of the MCP are evaluated by the project Supervisor based on both their assessment and assessments provided by SMEs and the project Client as depicted in Table 1. Supervisors may request that their Teams and Students include a self-assessment with their deliverables. Assessment and evaluation in the MCP has the objectives of being fair and flexible to Students and Supervisors (as presented in Table 2), given the wide variety MCP projects and Client expectations as well as simultaneously being comprehensive and rigorous, to ensure that Clients receive quality deliverables. Supervisors submit their evaluations to the Course Coordinator who is responsible for ensuring fairness across the different projects.

Table 1. Deliverables and weighting

\begin{tabular}{|c|c|c|c|}
\hline Deliverable & $\%$ & From & To \\
\hline Statement of Need & $N / A$ & Client & Course Coordinator \\
\hline Statement of Intent & $N / A$ & Student & $\begin{array}{l}\text { Departmental } \\
\text { Representative }\end{array}$ \\
\hline $\begin{array}{l}\text { Project } \\
\text { Requirements }\end{array}$ & \multirow{4}{*}{$65 \%$} & Team & Supervisor \& SMEs \\
\hline Design Proposal & & Team & $\begin{array}{l}\text { Supervisor, SMEs, and } \\
\text { Client }\end{array}$ \\
\hline Design Critique & & Team & $\begin{array}{l}\text { Supervisor, SMEs, and } \\
\text { Client }\end{array}$ \\
\hline $\begin{array}{l}\text { Final Report and } \\
\text { Deliverables }\end{array}$ & & Team & $\begin{array}{l}\text { Supervisor, SMEs, and } \\
\text { Client }\end{array}$ \\
\hline Design Showcase & $10 \%$ & Team & $\begin{array}{l}\text { Supervisor, SMEs, and } \\
\text { Client }\end{array}$ \\
\hline Design Portfolio & $25 \%$ & Student & $\begin{array}{l}\text { Supervisor \& } \\
\text { (optionally) SMEs }\end{array}$ \\
\hline
\end{tabular}

Because of the wide variety of MCP projects and Client expectations, some Teams may need to focus on the framing elements of the project (e.g. Project Requirements and Design Proposal) while others may focus on the implementation elements (e.g. the Design Critique and Final Report and Deliverables). Each Team is nonetheless expected to undertake all of the stages of a nominal engineering design project.

Table 2. Flexible deliverable weights

\begin{tabular}{|l|c|c|c|}
\hline \multicolumn{1}{|c|}{ Deliverable } & $\begin{array}{c}\text { Min } \\
\text { Weight }\end{array}$ & $\begin{array}{c}\text { Nominal } \\
\text { Weight }\end{array}$ & $\begin{array}{c}\text { Max } \\
\text { Weight }\end{array}$ \\
\hline Framing Deliverables & $10 \%$ & $15 \%$ & $30 \%$ \\
\hline Project Requirements & $5 \%$ & $10 \%$ & $30 \%$ \\
\hline Design Proposal & $10 \%$ & $15 \%$ & $30 \%$ \\
\hline Implementation Deliverables
\end{tabular}

\subsection{Student Teams}

The Student team executes all aspects of the design project (from Project Requirements to Poof of Concept).
Students are expected to negotiate conflicting objectives (that may arise due to differences in Supervisor, Client, Communication Instructor requirements).

Non-functional Team members are not being tolerated in this course. The team members are jointly responsible for:

- Producing high quality reports and presentations.

- Resolving conflicting input from stakeholders through open and effective communication.

- Working effectively as a member and leader in teams; hence ensuring smooth team dynamics.

- Submitting the attribution table (lists the tasks undertaken by the team and attributes them to members who contributed to the task).

\section{RESULTS AND DISCUSSION}

In comparison with the delivery and organization of the commonly implemented single-disciplinary capstone courses, as for example in the Mechanical Engineering program (ME), delivering the MCP course smoothly involved significant additional efforts in overcoming a number of unique challenges and difficulties that arise in pursuing some particular course processes and operations. Tables 3-6 briefly illustrate these issues. (Note: the number of projects in the following tables are based on the 2013-14 implementation of the courses).

Table 3. Project solicitation

\begin{tabular}{|l|l|}
\hline \multicolumn{1}{|c|}{ MCP } & \multicolumn{1}{c|}{ ME Capstone } \\
\hline Multidisciplinary $(\sim 20)$ & Discipline specific $(\sim 50)$ \\
\hline $\begin{array}{l}\text { Approved by engineering } \\
\text { departments }\end{array}$ & Approved by ME department \\
\hline $\begin{array}{l}\text { May require: } \\
\text { Export Control/NDA/IP }\end{array}$ & $\begin{array}{l}\text { May require: } \\
\text { Export Control/NDA/IP }\end{array}$ \\
\hline \multicolumn{2}{|l|}{ Challenging Process: Time consuming, check the quality, ... } \\
\hline
\end{tabular}

Table 4. Students matching

\begin{tabular}{|l|l|}
\multicolumn{2}{|c|}{ MCP } \\
$\begin{array}{l}\text { Require team members from at } \\
\text { least two disciplines }\end{array}$ & $\begin{array}{l}\text { 4th year ME Students are } \\
\text { enrolled }\end{array}$ \\
\hline $\begin{array}{l}\text { Requires approval by } \\
\text { engineering departments }\end{array}$ & $\begin{array}{l}\text { Approved by ME capstone } \\
\text { coordinator }\end{array}$ \\
\hline $\begin{array}{l}\text { Different deadlines, } \\
\text { expectations, scheduling }\end{array}$ & $\begin{array}{l}\text { Follow ME deadlines and ME } \\
\text { capstone requirements }\end{array}$ \\
\hline $\begin{array}{l}\text { Difficult task: Time consuming, competitive/may require } \\
\text { interviews, risk of cancelling projects, conflicts, ... }\end{array}$
\end{tabular}

Table 5. Supervisor/SME matching

\begin{tabular}{|l|l|}
\hline \multicolumn{2}{|c|}{ MCP } \\
$\begin{array}{l}\text { Supervised by a single APSc } \\
\text { faculty (10 or more) }\end{array}$ & $\begin{array}{l}\text { Supervised by a single ME } \\
\text { faculty (30 or more) }\end{array}$ \\
\hline $\begin{array}{l}\text { Co-supervised/access to SMEs (30 } \\
\text { or more) }\end{array}$ & No need for SMEs \\
\hline $\begin{array}{l}\text { May have issues with Students } \\
\text { background, competency... }\end{array}$ & $\begin{array}{l}\text { Familiar with Students and } \\
\text { their level of knowledge. }\end{array}$ \\
\hline $\begin{array}{l}\text { Challenges: Identify supervisors/SMEs, address questions } \\
\text { and/or concerns (e.g. course requirements, NDA/IP), loading, ... }\end{array}$
\end{tabular}


Table 6. Deliverables (Sept.-Apr.)

Table 6. Deliverables (Sept.-Apr.)
\begin{tabular}{|l|l|}
\multicolumn{2}{|c|}{ MCP } \\
\hline Project Requirements & Problem Statement \\
\hline Design Proposal & Project Requirements \\
\hline Design Review and Critique & Design Review \\
\hline Design Showcase & Design Showcase \\
\hline Final Design Specification & Final Design Specification \\
\hline Design Portfolio & \\
\hline
\end{tabular}

On the other hand, possible student team performance issues become even more pronounced in a multidisciplinary environment due to frustrations generated by the different academic backgrounds the students bring into the team. These issues may include:

- Differences in training and expectations among the team members based on their different program curriculums.

- Imbalance in contributions by team members.

- Lack of "effective communication."

- Unable to maintain a reasonable schedule.

- Failure to plan and execute a meeting resulting in a consensus decision.

\section{CONCLUSIONS}

UT-IMDI provides University of Toronto's FASE undergraduate and graduate Students with real-life training opportunities by involving them in practical, industry-based projects. It is a vehicle to promote awareness of design and development challenges facing industry, with an emphasis on its multidisciplinary nature, and evolving technology. A Faculty-wide multidisciplinary capstone course was developed and successfully implemented in 2013-2014 academic year. The 17 MCP projects were completed and showcased on March 20, 2014. This world-class course is well structured and implemented under the leadership of the NSERC Chair in "Multidisciplinary Design Engineering", and all FASE engineering programs' capstone design coordinators. Projects are developed by industry in close collaboration with UT-IMDI, and are based on real industry design and development needs. They gain experience working on a real engineering project in a real-life setting. It's good for their career whether they want to go to industry, or they want to go on to a graduate program. Ultimately, they gain a better understanding of what the real industry needs are.

\section{Acknowledgements}

We would like to acknowledge the great support and contributions of Dean Cristina Amon, MIE Chair Professor Jean $\mathrm{Zu}$ and all other FASE Engineering programs chairs, directors, and capstone design coordinator. Also the funding received from NSERC is greatly acknowledged.

\section{References}

[1] Engineers Canada, "Accreditation Criteria and Procedures Report 2013 (Accreditation Visit Cycle 2014 - 2015)," CEAB.

http://www.ingenieurscanada.ca/sites/default/files/sites/def ault/files/accreditation criteria procedures 2013.pdf

[2] ABET, Engineering Accreditation Commission (EAC), "2014-2015 Criteria for Accrediting Engineering Programs. http://www.abet.org/uploadedFiles/Accreditation/Accredita tion Step by Step/Accreditation Documents/Current/2014 - 2015/E001\%2014-15\%20EAC\%20Criteria\%203-1314(2).pdf

[3] "Industry Experience By Design," Momentum, Alumni and Industry Magazine, Volume 1, Issue 1, MIE, University of Toronto, http://imdi.mie.utoronto.ca/wpcontent/uploads/2014/01/Industry-Experience-by-DesignMomentum-Volume-1-Issue-1.pdf 